возбуждениях и сколь угодно больших промежутках времени. Явное решение упомянутой задачи находится посредством построения обратного матричного оператора и метода интегральных преобразований. Доказан также критерий разрешимости, обеспечивающий корректность физических/инженерных условий и математическую технику вычислений. Предложенный аналитический подход представляет часть общего метода, детально исследующего поведение электромагнитного поля в различных средах.

Ключевые слова: дифференциальная система Максвелла, общее волновое уравнение, краевая задача относительно напряженностей электромагнитного поля.

I.Yu. Dmitrieva. Analytical study of electromagnetic wave propagation in the finite homogeneous lines. The suggested results represent a special case of the general scientific trend dealing with mathematical modeling and analytical study of electromagnetic field phenomena described by the systems of PDEs (partial differential equations). A specific electrodynamic engineering process is specified by the differential Maxwell system whose effective research implies correct theoretical and physical statement in terms of the general wave PDE regarding all field intensities. Based on this equation, the corresponding boundary problem determines electromagnetic wave propagation in the isotropic homogeneous finite lines under expofunctional excitations and arbitrary large time intervals. Explicit solution of the aforesaid problem is found using inverse matrix operator construction and the integral transform method. Solvability criterion is also proved, supporting correctness of the physical/engineering conditions and mathematical computing technique. The proposed analytic approach represents part of the general method investigating electromagnetic field behavior for arbitrary media in detail.

Keywords: Maxwell differential system, general wave equation, boundary problem regarding electromagnetic field intensities.

Reviever Dr. techn. sciences, Prof. of Odesa nat. polytechnic univ. Maksimov M.V.

Received May 5, 2014

N.I. Kushnirenko, engineer, V.Ya. Chechelnytskyi, Dr. techn. sciences, Prof., Odes. Nat. Polytechn. Un-ty

\title{
DIGITAL MODULATION METHOD BASED ON PERFECT BINARY ARRAYS
}

Introduction. Modern telecommunication systems operating in a multipath propagation conditions must possess high resilience, robustness and secrecy. It is known [1] that the secrecy primarily determined by the energetic and parametric secrecy. Noise-like signals are commonly used to ensure communication secrecy. Such signals are built on the basis of certain algebraic structures.

Term "noise-like signals" is referred to the signals, for which the product of their bandwidth $F$ and elementary symbol duration $T$ is much greater than 1 . This product is called the processing gain and denoted as $B$, i.e. 78

$$
B=F T .
$$

For the noise-like signals the processing gain $B<1$. The wider bandwidth $F$ of noise-like signal, which is the spreading code (1), the higher the energetic and parametric secrecy of communication. The frequency of noise-like signals changing and their selection from the signal ensemble depends on many requirements to a communication system and can't be unambiguously determined [1].

Literature review. Noise-like signals can be designed using various structures. More recently, the heightened attention in domestic and foreign papers is paid to the application of Perfect Binary

DOI: 10.15276/opu.1.43.2014.37

(C) N.I. Kushnirenko, V.Ya. Chechelnytskyi, 2014

ЕЛЕКТРОНІКА. РАДІОТЕХНІКА. ЗАСОБИ ТЕЛЕКОМУНІКАЦІЙ 
Arrays (PBA) to solving of various problems of radio engineering, for example: encryption tasks; synthesis of antenna aperture; perfect time-frequency codes design; new classes of block error-correcting codes design; new classes of orthogonal, biorthogonal and minimax noise-like signals with the multiloop cyclic shift property design, etc. However, many problems in the theory of the PBA and their applications require further research.

The PBA is two-dimensional matrix of size $N \times N$ [2]

$$
\mathbf{P}(N)=\left\|p_{i, j}\right\|,
$$

where

$p_{i, j} \in\{+1,-1\}-$ elements of PBA;

$i=\overline{0, N-1}-$ numbers of rows of PBA;

$j=\overline{0, N-1}-$ numbers of columns of PBA.

Matrix (2) has an ideal two-dimensional periodic autocorrelation function (2D PACF)

$$
\mathbf{R}(N)=\left\|r_{m, n}\right\|=\left[\begin{array}{cccc}
N^{2} & 0 & \cdots & 0 \\
0 & 0 & \cdots & 0 \\
\vdots & \vdots & \ddots & \vdots \\
0 & 0 & \cdots & 0
\end{array}\right]
$$

where

$m=\overline{0, N-1}-$ numbers of 2D PACF rows;

$n=\overline{0, N-1}-$ numbers of 2D PACF columns.

Elements of 2D PACF (3) of PBA are calculated using equation

$$
r_{m, n}=\sum_{i=0}^{N-1} \sum_{j=0}^{N-1} p_{i, j} p_{i+m, j+n}=\left\{\begin{array}{l}
N^{2}, \text { when } m=n=0 \\
0, \text { others } m \text { and } n,
\end{array}\right.
$$

while values $i+m$ and $j+n$ are calculated modulo $N$.

An example of the PBA P(4) size of $4 \times 4$ and its 2D PACF $\mathbf{R}(4)$ respectively given below

$$
\mathbf{P}(4)=\left[\begin{array}{cccc}
+ & + & - & - \\
+ & + & + & + \\
- & + & + & - \\
- & + & - & +
\end{array}\right], \mathbf{R}(4)=\left[\begin{array}{cccc}
16 & 0 & 0 & 0 \\
0 & 0 & 0 & 0 \\
0 & 0 & 0 & 0 \\
0 & 0 & 0 & 0
\end{array}\right] .
$$

Here and further the elements of PBA "+1" and " -1 " denoted as "+" and "-" respectively.

There are known the PBAs of order $N=2^{k}$ and $N=3 \cdot 2^{k}$, where $k=1,2,3,4, \ldots$ is non-negative integer. The general equation to estimate the power of complete $U(N)$-class of PBA of arbitrary order, when $N=2^{k}>4$ is given below [3]

$$
\Psi_{U(N)}= \begin{cases}7^{(k-1) / 2} \cdot 3^{(k-1) / 2} \cdot 2^{2^{k+1}-1}, & \text { if } k \text { is odd; } \\ 7^{(k-2) / 2} \cdot 3^{k / 2} \cdot 2^{2^{k+1}-1}, & \text { if } k \text { is even. }\end{cases}
$$

For the complete $U(2)$-class of the PBA, the power (5) is $\Psi_{U(2)}=4$, for $U(4)$-class $\Psi_{U(4)}=384$ [3].

Research, given in this paper is performed within the Research work "Methods of informational security in broadband telecommunication systems", which is carried out by Information Security Department, Odessa National Polytechnic University. 
Aim of the research is to develop the method of information transfer using the PBAs, which is based on cyclic shifts of rows and/or columns of the base PBA.

The following problems must be solved to achieve this:

- Evaluate the properties of the PBAs while the cyclic shifts of its rows and/or columns are performed. class PBAs.

- Evaluate the properties of two-dimensional periodic cross-correlation functions of equivalence

- Elaborate digital modulation method, based on PBA's cross-correlation properties within equivalence class.

- Develop decoding method for equivalence class-built PBA signals.

Main Body. Consider the properties of the PBAs, which are dependent on cyclic shifts of matrix rows and columns.

Theorem 1. The 2D PACF of PBA $\mathbf{P}(N)$ is invariant regarding its cyclic column shift by $s(s<N)$ positions right (left). The shifted PBA can also be viewed as a new PBA with the same 2D PACF.

Proof. Indeed, if the elements of matrix $p_{i, j}$, which are cyclically shifted right by $s$ columns $p_{i, j+s}$ (it is equivalent to the cyclic shift by $N-S$ columns left) are substituted into (4) and taking into account that indices of $p$ are reduced modulo $N$, we obtain

$$
r_{m, n}=\sum_{i=0}^{N-1} \sum_{j=0}^{N-1} p_{i, j+s} p_{i+m, j+n+s}=\sum_{i=0}^{N-1} \sum_{j=0}^{N-1} p_{i, j} p_{i+m, j+n},
$$

which is equivalent considering sum permutation invariance.

For example, for PBA

$$
\mathbf{P}^{0}(4)=\left[\begin{array}{llll}
+ & + & - & - \\
+ & + & + & + \\
- & + & + & - \\
- & + & - & +
\end{array}\right]
$$

under cyclic shift of columns to the left, we obtain the following new structures of PBAs

$$
\begin{aligned}
\mathbf{P}^{0}(4) & =\left[\begin{array}{llll}
+ & + & - & - \\
+ & + & + & + \\
- & + & + & - \\
- & + & - & +
\end{array}\right], \mathbf{P}^{1}(4)=\left[\begin{array}{cccc}
+ & - & - & + \\
+ & + & + & + \\
+ & + & - & - \\
+ & - & + & -
\end{array}\right], \\
\mathbf{P}^{2}(4) & =\left[\begin{array}{llll}
- & - & + & + \\
+ & + & + & + \\
+ & - & - & + \\
- & + & - & +
\end{array}\right], \mathbf{P}^{3}(4)=\left[\begin{array}{cccc}
- & + & + & - \\
+ & + & + & + \\
- & - & + & + \\
+ & - & + & -
\end{array}\right] .
\end{aligned}
$$

Theorem 2. The 2D PACF of PBA $\mathbf{P}(N)$ is invariant to its cyclic row shift by $s(s<N)$ positions up (down). The shifted PBA can also be viewed as a new PBA with the same 2D PACF.

Proof. If the elements of matrix $p_{i, j}$, which are cyclically shifted down by $s$ rows $-p_{i+s, j}$ (it is equivalent to the cyclic shift by $N-s$ rows up) are substituted into (4) and taking into account that indexes of $p$ are reduced modulo $N$, we get next equation

$$
r_{m, n}=\sum_{i=0}^{N-1} \sum_{j=0}^{N-1} p_{i+s, j} p_{i+m+s, j+n}=\sum_{i=0}^{N-1} \sum_{j=0}^{N-1} p_{i, j} p_{i+m, j+n},
$$

which is equivalent considering sum permutation invariance.

For example, for PBA 


$$
\mathbf{P}^{0}(4)=\left[\begin{array}{llll}
+ & + & - & - \\
+ & + & + & + \\
- & + & + & - \\
- & + & - & +
\end{array}\right]
$$

under cyclic shift of rows up, we obtain the following new structures of PBAs

$$
\begin{aligned}
\mathbf{P}^{0}(4) & =\left[\begin{array}{llll}
+ & + & - & - \\
+ & + & + & + \\
- & + & + & - \\
- & + & - & +
\end{array}\right], \mathbf{P}^{1}(4)=\left[\begin{array}{cccc}
+ & + & + & + \\
- & + & + & - \\
- & + & - & + \\
+ & + & - & -
\end{array}\right], \\
\mathbf{P}^{2}(4) & =\left[\begin{array}{llll}
- & + & + & - \\
- & + & - & + \\
+ & + & - & - \\
+ & + & + & +
\end{array}\right], \mathbf{P}^{3}(4)=\left[\begin{array}{cccc}
- & + & - & + \\
+ & + & - & - \\
+ & + & + & + \\
- & + & + & -
\end{array}\right] .
\end{aligned}
$$

Property 1. Each PBA order of $N$ generates an equivalence class of matrices $-E(N)$-class of PBA by means of cyclic shift of rows and/or columns operations, the power of $E(N)$-class is given by

$$
\Psi_{E(N)}=N^{2} \text {. }
$$

Thus, any arbitrary PBA, which is built in any way, in fact, specifies the equivalence class of PBAs with the power (6).

This property is of practical importance for the design of the $E(N)$-class PBA generator since it is no longer necessary to store in the memory the structures of the PBAs of equivalence $E(N)$-class, the power of which increases exponentially with growth of order $N(5)$, and the number of elements in the PBA grows in proportion to $N^{2}$. In Table 1, as an example, the equivalence $E(4)$-class of PBAs is represented. It is constructed on the basis of the generator matrix

$$
\mathbf{P}(4)=\left[\begin{array}{llll}
+ & + & - & - \\
+ & + & + & + \\
- & + & + & - \\
- & + & - & +
\end{array}\right] .
$$

Indices $[k 1, k 2]$ next to the name of PBA (Table 1) indicate the number of positions by which rows and/or columns in the base (generator) $\operatorname{PBA} \mathbf{P}^{[0,0]}(4)$ is cyclically shifted, where $k 1$ denotes number of cyclic shifts of rows up, $k 2$ is number of cyclic shifts of columns to the left.

The concept of two-dimensional periodic cross-correlation function (2D PCCF) can now be introduced for arbitrary PBAs $\mathbf{P}^{0}(N)$ and $\mathbf{P}^{1}(N)$

$$
\mathbf{B}(N)=\left\|b_{m, n}\right\|,
$$

where the elements of 2D PCCF (7) for PBAs $\mathbf{P}^{0}(N)$ and $\mathbf{P}^{1}(N)$ are calculated using next equation

$$
b_{m, n}=\sum_{i=0}^{N-1} \sum_{j=0}^{N-1} p_{i, j}^{0} p_{i+m, j+n}^{1} .
$$

Theorem 3. For any given PBA $\mathbf{P}^{0}(N)$ and any $\operatorname{PBA} \mathbf{P}^{1}(N)$, obtained from $\mathbf{P}^{0}(N)$ by cyclic column shift by $s$ positions, the 2D PCCF of $\mathbf{P}^{0}(N)$ and $\mathbf{P}^{1}(N)$ is equal to $2 \mathrm{D}$ PACF of $\mathbf{P}^{0}(N)$ with the same column shift. 
Equivalence E(4)-class of PBAs

\begin{tabular}{|c|c|c|c|c|c|c|c|c|c|c|c|c|c|c|c|c|c|c|c|}
\hline $\mathbf{P}^{[0,0]}(4)=$ & {$\left[\begin{array}{l}+ \\
+ \\
- \\
-\end{array}\right.$} & $\begin{array}{l}+ \\
+ \\
+ \\
+\end{array}$ & $\begin{array}{l}- \\
+ \\
+ \\
-\end{array}$ & $\left.\begin{array}{l}- \\
+ \\
- \\
+\end{array}\right]$ & $\mathbf{P}^{[0,1]}(4)=$ & $\begin{array}{l}+ \\
+ \\
+\end{array}$ & $\begin{array}{l}- \\
+ \\
+ \\
-\end{array}$ & $\begin{array}{l}- \\
+ \\
- \\
+\end{array}$ & $\left.\begin{array}{l}+ \\
+ \\
- \\
-\end{array}\right]$ & $\mathbf{P}^{[0,2]}(4)=$ & {$\left[\begin{array}{l}- \\
+ \\
+ \\
-\end{array}\right.$} & $\begin{array}{l}- \\
+ \\
- \\
+\end{array}$ & $\begin{array}{l}+ \\
+ \\
- \\
-\end{array}$ & $\left.\begin{array}{l}+ \\
+ \\
+ \\
+\end{array}\right]$ & $\mathbf{P}^{[0,3]}(4)=$ & {$\left[\begin{array}{l}- \\
+ \\
- \\
+\end{array}\right.$} & $\begin{array}{l}+ \\
+ \\
- \\
-\end{array}$ & $\begin{array}{l}+ \\
+\end{array}$ & $\left.\begin{array}{l}- \\
+ \\
+ \\
-\end{array}\right]$ \\
\hline $\mathbf{P}^{[1,0]}(4)=$ & {$\left[\begin{array}{l}+ \\
- \\
- \\
+\end{array}\right.$} & $\begin{array}{l}+ \\
+ \\
+\end{array}$ & $\begin{array}{l}+ \\
+ \\
- \\
-\end{array}$ & $\left.\begin{array}{l}+ \\
- \\
+ \\
-\end{array}\right]$ & $\mathbf{P}^{[1,1]}(4)=$ & $\begin{array}{l}+ \\
+ \\
+ \\
+ \\
+\end{array}$ & $\begin{array}{l}+ \\
+ \\
- \\
-\end{array}$ & $\begin{array}{l}+ \\
- \\
+ \\
-\end{array}$ & $\left.\begin{array}{l}+ \\
- \\
- \\
+\end{array}\right]$ & $\mathbf{P}^{[1,2]}(4)=$ & {$\left[\begin{array}{l}+ \\
+ \\
- \\
-\end{array}\right.$} & $\begin{array}{l}+ \\
- \\
+ \\
-\end{array}$ & $\begin{array}{l}+ \\
- \\
- \\
+\end{array}$ & $\left.\begin{array}{l}+ \\
+ \\
+ \\
+\end{array}\right]$ & $\mathbf{P}^{[1,3]}(4)=$ & {$\left[\begin{array}{l}+ \\
- \\
+ \\
-\end{array}\right.$} & $\begin{array}{l}+ \\
- \\
- \\
+\end{array}$ & + & $\left.\begin{array}{l}+ \\
+ \\
- \\
-\end{array}\right]$ \\
\hline $\mathbf{P}^{[2,0]}(4)=$ & {$\left[\begin{array}{l}- \\
- \\
+ \\
+\end{array}\right.$} & + & $\begin{array}{l}+ \\
- \\
- \\
+\end{array}$ & $\left.\begin{array}{l}- \\
+ \\
- \\
+\end{array}\right]$ & $\mathbf{P}^{[2,1]}(4)=$ & $\begin{array}{l}+ \\
+\end{array}$ & $\begin{array}{l}+ \\
- \\
- \\
+\end{array}$ & $\begin{array}{l}- \\
+ \\
- \\
+\end{array}$ & $\left.\begin{array}{l}- \\
- \\
+ \\
+\end{array}\right]$ & $\mathbf{P}^{[2,2]}(4)=$ & {$\left[\begin{array}{l}+ \\
- \\
- \\
+\end{array}\right.$} & $\begin{array}{l}- \\
+ \\
- \\
+\end{array}$ & $\begin{array}{l}- \\
- \\
+ \\
+\end{array}$ & $\left.\begin{array}{l}+ \\
+ \\
+ \\
+\end{array}\right]$ & $\mathbf{P}^{[2,3]}(4)=$ & {$\left[\begin{array}{l}- \\
+ \\
- \\
+\end{array}\right.$} & $\begin{array}{l}- \\
- \\
+ \\
+\end{array}$ & + & $\begin{array}{l}+ \\
- \\
- \\
+\end{array}$ \\
\hline $\mathbf{P}^{[3,0]}(4)=$ & {$\left[\begin{array}{l}- \\
+ \\
+ \\
-\end{array}\right.$} & + & $\begin{array}{l}- \\
- \\
+ \\
+\end{array}$ & $\left.\begin{array}{l}+ \\
- \\
+ \\
-\end{array}\right]$ & $\mathbf{P}^{[3,1]}(4)=$ & {$\left[\begin{array}{l}+ \\
+ \\
+\end{array}\right.$} & $\begin{array}{l}- \\
- \\
+ \\
+\end{array}$ & $\begin{array}{l}+ \\
- \\
+ \\
-\end{array}$ & $\left.\begin{array}{l}- \\
+ \\
+ \\
-\end{array}\right]$ & $\mathbf{P}^{[3,2]}(4)=$ & {$\left[\begin{array}{l}- \\
- \\
+ \\
+\end{array}\right.$} & $\begin{array}{l}+ \\
- \\
+ \\
-\end{array}$ & $\begin{array}{l}- \\
+ \\
+ \\
-\end{array}$ & $\left.\begin{array}{l}+ \\
+ \\
+ \\
+\end{array}\right]$ & $\mathbf{P}^{[3,3]}(4)=$ & {$\left[\begin{array}{l}+ \\
- \\
+ \\
-\end{array}\right.$} & $\begin{array}{l}- \\
+ \\
+ \\
-\end{array}$ & + & $\left.\begin{array}{l}- \\
- \\
+ \\
+\end{array}\right]$ \\
\hline
\end{tabular}

Proof. By substituting elements $p_{i, j}^{1}$ with $p_{i, j+s}^{0}$ (which are equivalent to $p_{i, j}^{0}$ cyclically shifted right by $s$ columns or $N-s$ left) in (8), we get

$$
b_{m, n}=\sum_{i=0}^{N-1} \sum_{j=0}^{N-1} p_{i, j}^{0} p_{i+m, j+n+s}^{0},
$$

and taking into account that the indices of $p$ are calculated modulo $N$, we get

$$
r_{m, n+s}=\sum_{i=0}^{N-1} \sum_{j=0}^{N-1} p_{i, j}^{0} p_{i+m, j+n+s}^{0},
$$

Q.E.D.

Theorem 4. For any given PBA $\mathbf{P}^{0}(N)$ and any $\operatorname{PBA} \mathbf{P}^{1}(N)$, obtained from $\mathbf{P}^{0}(N)$ by cyclic row shift by $s$ positions, the 2D PCCF of $\mathbf{P}^{0}(N)$ and $\mathbf{P}^{1}(N)$ is equal to $2 \mathrm{D} \mathrm{PACF}$ of $\mathbf{P}^{0}(N)$ with the same row shift.

Proof. By substituting elements $p_{i, j}^{1}$ with $p_{i+s, j}^{0}$ (which are equivalent to $p_{i, j}^{0}$ cyclically shifted down by $s$ rows or $N-s$ up) in (8), we get

$$
b_{m, n}=\sum_{i=0}^{N-1} \sum_{j=0}^{N-1} p_{i, j}^{0} p_{i+m+s, j+n}^{0},
$$

and taking into account that the indices of $p$ are calculated modulo $N$, we get

$$
r_{m+s, n}=\sum_{i=0}^{N-1} \sum_{j=0}^{N-1} p_{i, j}^{0} p_{i+m+s, j+n}^{0}
$$

Q.E.D.

Results. In the Table 2, as an example, the 2D PCCFs of base (generator) matrix

$$
\mathbf{P}(4)=\left[\begin{array}{llll}
+ & + & - & - \\
+ & + & + & + \\
- & + & + & - \\
- & + & - & +
\end{array}\right] .
$$


of order $N=4$ with cyclic shifts parameters of rows and columns $[0,0]$ and all the other matrices of equivalence $E(4)$-class of PBAs from the Table 1 with parameters of cyclic shift $[k 1, k 2]$ are given.

Table 2

2D PCCF of the PBAs of equivalence E(4)-class

\begin{tabular}{|c|c|c|c|c|c|c|c|c|c|c|c|c|c|c|c|c|c|c|c|}
\hline \multirow{4}{*}{$\mathbf{B}^{[0,0]}(4)=$} & $\lceil 16$ & 0 & 0 & 07 & \multirow{4}{*}{$\mathbf{B}^{[0,1]}(4)=$} & {$[0$} & 16 & 0 & 07 & \multirow{4}{*}{$\mathbf{B}^{[0,2]}(4)=$} & {$[0$} & 0 & 16 & 0 & \multirow{4}{*}{$\mathbf{B}^{[0,3]}(4)=$} & {$[0$} & 0 & 0 & 16 \\
\hline & 0 & 0 & 0 & 0 & & 0 & 0 & 0 & 0 & & 0 & 0 & 0 & 0 & & 0 & 0 & 0 & 0 \\
\hline & 0 & 0 & 0 & 0 & & 0 & 0 & 0 & 0 & & 0 & 0 & 0 & 0 & & 0 & 0 & 0 & 0 \\
\hline & 0 & 0 & 0 & 0 & & 0 & 0 & 0 & 0 & & 0 & 0 & 0 & 0 & & 0 & 0 & 0 & 0 \\
\hline \multirow{4}{*}{$\mathbf{B}^{[1,0]}(4)=$} & 0 & 0 & 0 & 07 & \multirow{4}{*}{$\mathbf{B}^{[1,1]}(4)=$} & 0 & 0 & 0 & 07 & \multirow{4}{*}{$\mathbf{B}^{[1,2]}(4)=$} & 0 & 0 & 0 & 07 & \multirow{4}{*}{$\mathbf{B}^{[1,3]}(4)=$} & 0 & 0 & 0 & 07 \\
\hline & 16 & 0 & 0 & 0 & & 0 & 16 & 0 & 0 & & 0 & 0 & 16 & 0 & & 0 & 0 & 0 & 16 \\
\hline & 0 & 0 & 0 & 0 & & 0 & 0 & 0 & 0 & & 0 & 0 & 0 & 0 & & 0 & 0 & 0 & 0 \\
\hline & 0 & 0 & 0 & $0\rfloor$ & & 0 & 0 & 0 & 0 & & 0 & 0 & 0 & $0\rfloor$ & & 0 & 0 & 0 & $0\rfloor$ \\
\hline \multirow{4}{*}{$\mathbf{B}^{[2,0]}(4)=$} & 0 & 0 & 0 & 07 & \multirow{4}{*}{$\mathbf{B}^{[2,1]}(4)=$} & {$[0$} & 0 & 0 & 07 & \multirow{4}{*}{$\mathbf{B}^{[2,2]}(4)=$} & {$[0$} & 0 & 0 & 07 & \multirow{4}{*}{$\mathbf{B}^{[2,3]}(4)=$} & {$[0$} & 0 & . & 0 \\
\hline & 0 & 0 & 0 & 0 & & 0 & 0 & 0 & 0 & & 0 & 0 & 0 & 0 & & 0 & 0 & 0 & 0 \\
\hline & 16 & 0 & 0 & 0 & & 0 & 16 & 0 & 0 & & 0 & 0 & 16 & 0 & & 0 & 0 & 0 & 16 \\
\hline & 0 & 0 & 0 & 0 & & 0 & 0 & 0 & 0 & & 0 & 0 & 0 & 0 & & 0 & 0 & 0 & 0 \\
\hline \multirow{4}{*}{$\mathbf{B}^{[3,0]}(4)=$} & 0 & 0 & 0 & 07 & \multirow{4}{*}{$\mathbf{B}^{[3,1]}(4)=$} & {$[0$} & 0 & 0 & 07 & \multirow{4}{*}{$\mathbf{B}^{[3,2]}(4)=$} & {$[0$} & 0 & 0 & 0 & \multirow{4}{*}{$\mathbf{B}^{[3,3]}(4)=$} & {$[0$} & 0 & 0 & 0 \\
\hline & 0 & 0 & 0 & 0 & & 0 & 0 & 0 & 0 & & 0 & 0 & 0 & 0 & & 0 & 0 & 0 & 0 \\
\hline & 0 & 0 & 0 & 0 & & 0 & 0 & 0 & 0 & & 0 & 0 & 0 & 0 & & 0 & 0 & 0 & 0 \\
\hline & 16 & 0 & 0 & 0 & & 0 & 16 & 0 & $0\rfloor$ & & 0 & 0 & 16 & 0 & & 0 & 0 & 0 & 16 \\
\hline
\end{tabular}

As follows from Table 2, the 2D PCCF of base PBA and PBA, the rows and/or columns of which are cyclically shifted relative to the base PBA, contains one peak. The energy of this peak is $E=N^{2}$. The shifts of this peak relative to its location in 2D PACF determine unambiguously the number of cyclic shifts of rows and/or columns of the base PBA.

Equations (9) and (10) are of great practical importance, since it is, in fact, strict grounding of digital modulation method based on the cyclic shifts of base PBA.

Theorem 3 and 4 define the technique of signal decoding, constructed on the basis of the equivalence $E(N)$-class of PBAs. From analysis of Table 2 follows, that in case of $N^{2}$ signals of $E(N)$-class detection by receiver, a single two-dimensional matched filter is needed. It must be built on the basis of the filter signal - the base PBA, and 2D PCCF maximum search scheme. In general case, $N^{2}$ twodimensional matched filters required for optimum detection of arbitrary structure signals.

Conclusions. The paper is focused on PBA correlation properties regarding to cyclic shifts of PBA rows and/or columns. Also, the properties of two-dimensional periodic cross-correlation functions of PBAs equivalence class are discussed.

The digital modulation method based on PBA equivalence class is elaborated. This method is easy to implement in hardware, since the shifting device is much easier to implement than the PBA generator.

A set of theorems regarding PBAs 2D PCCF formed a basis which allowed for elaboration of novel PBA detection method which in general case allows to reduce the complexity of receiver $N^{2}$ times.

\section{Literature}

1. Methods of improving information security by integrating multiplexing, ciphering and channel encoding operations / M.I. Mazurkov, V.Ya. Chechelnytskyi, A.N. Meleshkevich, at al. // Radioelectronics and Communications Systems. - 2011. - Vol. 54, Iss. 5. - PP. 227 - 240.

2. Song, Y.J. Design of Almost Perfect Complementary Sequence Pairs / Y.J. Song // International Journal of Multimedia and Ubiquitous Engineering. - 2013. - Vol. 8, No. 6. - PP. 303 - 312.

3. Кушниренко, Н.И. Принципы информационной модуляции и демодуляции сигналов на основе совершенных двоичных решеток / Н.И. Кушниренко, В.Я. Чечельницкий // Матеріали Другої Всеукраїнської Інтернетконференції “Українська наука: реалії та перспективи”, 30-31 березня 2011 р., Тернопіль. — С. 11 - 13. 


\section{References}

1. Methods of improving information security by integrating multiplexing, ciphering and channel encoding operations / M.I. Mazurkov, V.Ya. Chechelnytskyi, A.N. Meleshkevich at al. // Radioelectronics and Communications Systems. - 2011. - Vol. 54, Iss. 5. - pp. 227 - 240.

2. Song, Y.J. Design of Almost Perfect Complementary Sequence Pairs / Y.J. Song // International Journal of Multimedia and Ubiquitous Engineering. - 2013. - Vol. 8, No. 6. - pp. $303-312$.

3. Kushnirenko, N.I., Printsipy informatsionnoy modulyatsii i demodulyatsii signalov na osnove sovershennykh dvoichnykh reshetok [Principles of information modulation and demodulation of signals based on the perfect binary arrays] / N.I. Kushnirenko, V.Ya. Chechel'nitskiy // Materialy Druhoi Vseukrainskoi Internet-konferentsii "Ukrainska nauka: realii ta perspekty-vy", 30-31 bereznia $2011 \mathrm{r}$. [Proceedings of the 2-nd Internet conference "Ukrainian Science: Realities and Prospects", 30-31 March, 2011], Ternopil. — pp. 11 - 13.

\section{AHOTАЩІЯ / АННОТАЦИЯ / ABSTRACT}

Н.І. Кушніренко, В.Я. Чечельницький. Метод інформаційної модуляції на базі досконалих двійкових решіток. Метою $є$ розробка методу передачі інформації на базі досконалих двійкових решіток, який заснований на їх структурних і кореляційних властивостях. Представлено і доведено властивості еквівалентного класу досконалих двійкових решіток. На основі властивостей двовимірних періодичних взаємнокореляційних функцій між базовою досконалою двійковою решіткою і всіма іншими решітками еквівалентного класу запропоновано метод інформаційної модуляції. Даний метод може бути використаний для передачі дискретних цифрових повідомлень за допомогою циклічних широкосмугових сигналів, при цьому декодування цих сигналів може здійснюватися за допомогою єдиного узгодженого з опорною досконалою двійковою решіткою фільтра. Запропонований метод дозволяє спростити апаратну реалізацію пристроїв розрізнення сигналів і вирішити головну проблему радіозв'язку - істотно спростити схему декодера. Отримані результати можуть знайти застосування в одноканальних синхронних системах зв'язку 3 шумоподібними двовимірними циклічними сигналами.

Ключові слова: досконала двійкова решітка, метод модуляції, еквівалентний клас, широкосмуговий сигнал.

Н.И. Кушниренко, В.Я. Чечельницкий. Метод информационной модуляции на базе совершенных двоичных решеток. Целью является разработка метода передачи информации на базе совершенных двоичных решеток, который основан на их структурных и корреляционных свойствах. В работе представлены и доказаны свойства эквивалентного класса совершенных двоичных решеток. На основе свойств двумерных периодических взаимнокорреляционных функций между базовой совершенной двоичной решеткой и всеми остальными решетками эквивалентного класса предложен метод информационной модуляции. Данный метод может быть использован для передачи дискретных цифровых сообщений с помощью циклических широкополосных сигналов, при этом декодирование этих сигналов может осуществляться с помощью единственного согласованного с опорной совершенной двоичной решеткой фильтра. Предложенный метод позволяет упростить аппаратную реализацию устройств различения сигналов и решить главную проблему радиосвязи - существенно упростить схему декодера. Полученные результаты могут найти применение в одноканальных синхронных системах связи с шумоподобными двумерными циклическими сигналами.

Ключевые слова: совершенная двоичная решетка, метод модуляции, эквивалентный класс, широкополосный сигнал.

N.I. Kushnirenko, V.Ya. Chechelnytskyi. Digital modulation method based on perfect binary arrays. The aim is to develop the method of information transfer using perfect binary arrays, which is based on their structural and correlation properties. The properties of the equivalence class of perfect binary arrays are presented and proved in the paper. On the basis of the properties of two-dimensional periodic cross-correlation functions between a base array and all the rest perfect binary arrays within the equivalence class the digital modulation method is proposed. This method can be used for transmission of discrete digital messages by means of cyclic wideband signals. The decoding of these signals can be implemented with a single filter matched with base perfect binary array. The proposed method can simplify hardware implementation of signal detection devices and solve the main problem of the radio communication, namely, greatly simplify the decoder circuit. The obtained results can be used in single channel synchronous communication systems with noise-like two-dimensional cyclic signals.

Keywords: perfect binary array, digital modulation method, equivalence class, broadband/wideband signal.

Reviever Dr. techn. sciences, Prof. of Odesa nat. polytechnic univ. Mazurkov M.I. 